\title{
Effect of pressure at primary drying of freeze-drying mouse sperm reproduction ability and preservation potential
}

\author{
Yosuke Kawase, Toshio Hani, Nobuo Kamada, Kou-ichi Jishage and Hiroshi Suzuki 1,2 \\ Chugai Research Institute for Medical Science, Inc., Shizuoka, Japan, ${ }^{1}$ Research Unit for Functional Genomics, \\ National Research Center for Protozoan Diseases, Obihiro University of Agriculture and Veterinary Medicine, \\ Obihiro, Hokkaido, Japan and ${ }^{2}$ Department of Developmental and Medical Technology, Graduate School of \\ Medicine, The University of Tokyo, Tokyo, Japan
}

Correspondence should be addressed to H Suzuki; Email: hisuzuki@obihiro.ac.jp

\begin{abstract}
Freeze-dried spermatozoa are capable of participating in normal embryonic development after injection into oocytes and thus useful for the maintenance of genetic materials. We recently reported that long-term preservation of freeze-dried mouse spermatozoa by conventional methods requires temperatures lower than $-80^{\circ} \mathrm{C}$. Successful permanent preservation of mouse spermatozoa at much higher temperatures requires thorough investigation of the freeze-drying procedure. Thus, we examined the relationship between the pressure at primary drying and the preservation potential of freeze-dried mouse spermatozoa. Three different primary drying pressures were applied to evaluate the effect of pressure on freeze-dried spermatozoa under varying storage conditions and the rate of development measured. The developmental rate of embryos to the blastocyst stage from intracytoplasmic sperm injection by freeze-dried spermatozoa at pressures of $0.04,0.37$, and 1.03 mbar without storage were $59 \%(337 / 576), 71 \%(132 / 187)$, and $33 \%(99 / 302)$ respectively. When stored at $4{ }^{\circ} \mathrm{C}$ for 6 months, the rate was $13 \%(48 / 367)$, $50 \%(73 / 145)$, and $36 \%(66 / 182)$ respectively. These results show that primary drying pressure is an influential factor in the long-term preservation of freeze-dried mouse spermatozoa.

Reproduction (2007) 133 841-846
\end{abstract}

\section{Introduction}

In the last decade, numerous reports have shown that freeze-dried mouse spermatozoa are capable of participating in normal embryonic development after injection into oocytes (Wakayama \& Yanagimachi 1998, Kusakabe et al. 2001, Kaneko et al. 2003a,b, Ward et al. 2003, Kawase et al. 2005). Freeze-dried mouse spermatozoa are most efficiently stored for extended periods, several to tens of decades, at temperatures lower than $-80^{\circ} \mathrm{C}$ (Kawase et al. 2005). However, maintaining such low temperatures over a long period of time puts the samples at risk of loss from technical difficulties (e.g. power failure) and requires a relatively high initial investment. Although freeze-dried spermatozoa can be stored for 1.5 years (Ward et al. 2003), this length of time is insufficient for either the maintenance of genetically modified mouse strains or mutant mice in saturation mutagenesis projects. Long-term preservation at ambient temperatures would be ideal. The freeze-drying process is of importance, especially the primary drying process; however, no study of pressure at primary drying of spermatozoa has been reported. Here, we focused on the pressure at primary drying and found 0.37 mbar to be the optimum pressure for preservation of freeze-dried mouse spermatozoa at much higher temperatures.

\section{Materials and Methods}

\section{Animals}

F1 (B6C3F1) mice were purchased from Clea Japan (Tokyo, Japan). All the mice were housed in polycarbonate cages and maintained under a specific pathogenfree environment in light-controlled lights on from 0500 to $1900 \mathrm{~h}$ and air-conditioned rooms (temperature, $24 \pm$ $1{ }^{\circ} \mathrm{C}$; humidity, $\left.50 \pm 10 \%\right)$. The mice had free access to standard laboratory chow (CE-2, Clea Japan). The Institutional Animal Care and Use Committee of Chugai Pharmaceutical reviewed the protocols and confirmed that the animals used in this study were cared for and used under the Guiding Principles for the Care and Use of Research Animals promulgated by Chugai Pharmaceutical. 


\section{Freeze-drying and preservation of spermatozoa}

The procedure for freeze-drying was essentially the same as that described by Kaneko et al. (2003a) and Kawase et al. (2005). The six epididymides from three B6C3F1 male mice were removed and a dense sperm mass was squeezed out of each cauda epididymis from a cut made with scissors. The total sperm mass was gently placed in $9 \mathrm{ml}$ EGTA Tris-HCl-buffered solution $(50 \mathrm{mM}$ EGTA, $50 \mathrm{mM} \mathrm{NaCl}$, and $10 \mathrm{mM}$ Tris- $\mathrm{HCl}, \mathrm{pH}$ 8.0; Kaneko et al. 2003a) in a tube (352059, Becton Dickinson Labware, NJ, USA) and kept at $37^{\circ} \mathrm{C}$ for $10 \mathrm{~min}$. The sperm suspension at a concentration of $15-38 \times 10^{6}$ cell $\mathrm{s} / \mathrm{ml}$ was divided into 18 aliquots. Each aliquot of $500 \mu \mathrm{l}$ was put into an amber vacuum vial for freezedrying (V-2B, Nichiden-rika Glass Co. Ltd., Kobe, Japan). The vials were plunged into liquid nitrogen $\left(\sim-196^{\circ} \mathrm{C}\right)$ for $5 \mathrm{~min}$ and then transferred to a programmable freezedryer (BETA2-16, Martin Christ Gefriertrocknungsanlagen $\mathrm{GmbH}$, Osterode am Harz, Germany), which had been pre-cooled to $-30{ }^{\circ} \mathrm{C}$. The freeze-drying conditions consisted of primary drying at a pressure of 0.04 mbar for $8 \mathrm{~h}, 0.37$ mbar for $13 \mathrm{~h}$, or 1.03 mbar for $13 \mathrm{~h}$ and secondary drying at a pressure of $0.001 \mathrm{mbar}$ for $6 \mathrm{~h}$. More time is required for complete drying when lower pressures are provided at primary drying. The inside pressure of the vials at the time of sealing was $0.001 \mathrm{mbar}$ and pressure reduction was within $5 \mathrm{~min}$. The vials were stored at 4 or $30{ }^{\circ} \mathrm{C}$ until use. Immediately before ICSI, the vials of freeze-dried spermatozoa were unsealed, and the spermatozoa were hydrated by adding $500 \mu \mathrm{l}$ sterile distilled water. To maintain a similar composition of sperm suspension before and after freeze-drying, distilled water was added rather than a medium such as Hepes-buffered culture medium.

\section{Comet assay for DNA damage}

DNA damage of the spermatozoa from freeze-drying and subsequent preservation was assessed by single-cell gel electrophoresis (comet assay; Hughes et al. 1997, Steel et al. 1999, Cho et al. 2003). Evaluation of the shape of the DNA 'comet' tail and migration pattern gives an assessment of DNA damage. The sperm suspension was suspended in Comet LMAgarose (1\% low-temperature melting agarose, Trevigen, Gaithersburg, MD, USA) at a ratio $1: 10(\mathrm{v} / \mathrm{v})$. With the addition of molten LMAgarose at $37{ }^{\circ} \mathrm{C}, 25 \mu \mathrm{l}$ sperm suspension was immediately placed on a CometSlide (Trevigen). The slides were placed flat in a refrigerator at $4{ }^{\circ} \mathrm{C}$ for $10 \mathrm{~min}$ and then submerged in $23 \mathrm{ml}$ lysis solution (Trevigen) at $4{ }^{\circ} \mathrm{C}$ for $60 \mathrm{~min}$. Next, $2.5 \mathrm{ml} 10 \mathrm{mM}$ dithiothreitol was added and the slides were then incubated for $30 \mathrm{~min}$ at $4{ }^{\circ} \mathrm{C}$, followed by the addition of $2.5 \mathrm{ml}$ of $4 \mathrm{mM}$ LIS (lithium diiodosalicylate) and incubation for $90 \mathrm{~min}$ at room temperature. The slides were then kept in an alkaline solution ( $>\mathrm{pH} 13)$ for $20 \mathrm{~min}$ at room temperature in the darkness. The slides were subjected to electrophoresis in $1 \times$ TBE (Tris-borate EDTA) buffer at $25 \mathrm{~V}$ for $10 \mathrm{~min}$, stained with SYBR Green (Trevigen), and analyzed under a microscope (IX-70, Olympus Co., Tokyo, Japan). DNA damage of freeze-dried spermatozoa was assessed by Comet assay twice per experimental group. Comet tail length is the distance the damaged DNA has migrated from the sperm head and gives an estimate of the extent of the damage.

\section{Preparation of oocytes}

Mature B6C3F1 females were induced to superovulate by i.p. injections of $5 \mathrm{IU}$ equine chorionic gonadotropin (Serotrophin, Teikokuzoki Co., Tokyo, Japan) and 5 IU human chorionic gonadotropin (hCG; Puberogen, Sankyo Co., Tokyo, Japan) $48 \mathrm{~h}$ later. Freshly ovulated oocytes were collected from oviducts 15-16 h after being injected with hCG. The oocytes were treated with $0.1 \%$ hyaluronidase (280 units/mg; H-3506, SIGMA Chemical Co.) in Whitten's medium (Whitten 1971) supplemented with $100 \mu \mathrm{M}$ ethylene diamine tetraacetic acid disodium salt (EDTA; Abramczuk et al. 1977) to remove cumulus cells.

\section{Intracytoplasmic sperm injection}

After rehydration of the freeze-dried spermatozoa as described above, one part of the sperm suspension was thoroughly mixed with nine parts $0.9 \% \mathrm{NaCl}$ solution (saline) containing $12 \%(\mathrm{w} / \mathrm{v})$ polyvinyl pyrrolidone (PVP, No. 99219, Mt. 360 000, Irvine Scientific, Santa Ana, CA, USA). Two drops $(\sim 5 \mu \mathrm{l}$ each) of $12 \%$ PVP saline and two drops of $20 \mathrm{mM}$ Hepes-buffered Whitten's medium containing $0.1 \%$ polyvinyl alcohol (PVA, P-8136, MW 30 000-70 000, Sigma) were linearly placed on the injection chamber (Kawase et al. 2001) and then covered with mineral oil (M-8410, embryo tested, Sigma). The first drop of $12 \%$ PVP saline was used to wash the injection pipette, and added to the second drop was $1-2 \mu \mathrm{l}$ of the diluted sperm suspension. The first drop of the medium was used to remove spermatozoa that had attached to the surface of the injection pipette. The cumulus-free oocytes were placed in the second drop of Hepes-buffered Whitten's medium. The injection chamber with the spermatozoa and oocytes was transferred onto the stage of an inverted microscope maintained at $\sim 18{ }^{\circ} \mathrm{C}$ (MATS-555RSP, Tokai Hit, Shizuoka, Japan).

The procedure for micromanipulation of the sperm for ICSI was essentially the same as that described previously (Kimura \& Yanagimachi 1995, Kawase et al. 2001). The sperm head was separated from the tail by applying three or four piezo pulses (controller setting: speed 2, intensity 2) to the head-tail junction of the spermatozoon. In the same manner, a total of 3-5 
Table 1 Effect of vacuum pressure at primary drying on the in vitro development of embryos generated by ICSI of freeze-dried, non-stored spermatozoa.

\begin{tabular}{lccccc}
\hline $\begin{array}{l}\text { Vacuum pressure } \\
\text { (mbar) }\end{array}$ & $\begin{array}{c}\text { No. of oocytes } \\
\text { injected }\end{array}$ & $\begin{array}{c}\text { No. }(\%) \text { of oocytes } \\
\text { survived }\end{array}$ & $\begin{array}{c}\text { No. }(\%) \text { of oocytes } \\
\text { fertilized }^{\mathrm{a}}\end{array}$ & $\begin{array}{c}\text { No. }(\%) \text { of embryos } \\
\text { developed to two-cell }^{\mathrm{b}}\end{array}$ & $\begin{array}{c}\text { No. (\%) of embryos } \\
\text { developed to blastocyst }^{\mathrm{b}}\end{array}$ \\
\hline 0.04 & 864 & $608(70)^{\mathrm{a}}$ & $576(95)^{\mathrm{a}}$ & $557(97)^{\mathrm{a}}$ & $337(59)^{\mathrm{a}}$ \\
0.37 & 253 & $194(77)^{\mathrm{ab}}$ & $187(96)^{\mathrm{a}}$ & $181(97)^{\mathrm{a}}$ & $132(71)^{\mathrm{b}}$ \\
1.03 & 404 & $317(78)^{\mathrm{b}}$ & $302(95)^{\mathrm{a}}$ & $288(95)^{\mathrm{a}}$ & $99(33)^{\mathrm{c}}$ \\
\hline
\end{tabular}

Different superscript letters within a column indicate significantly different values $(P<0.05)$.

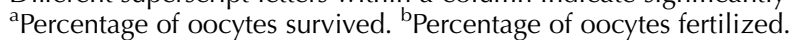

isolated sperm heads were lined up in the pipette. Several piezo pulses (controller setting: speed 2, intensity 2) were applied to advance the tip of the injection pipette to the surface of zona pellucida; the pipette was advanced mechanically while applying slightly negative pressure. The oolemma was punctured using 1-2 piezo pulses (controller setting: speed 1, intensity 1). A single sperm head was then expelled into the ooplasm accompanied with a minimum amount of medium. Following retrieval of as much as possible of the medium, the injection pipette was withdrawn while applying negative pressure to the pipette.

\section{Culture of oocytes and embryos transfer}

Sperm-injected oocytes were incubated and cultured in Whitten's medium supplemented with $100 \mu \mathrm{M}$ EDTA at $37.5{ }^{\circ} \mathrm{C}$ in $5 \% \mathrm{CO}_{2}$ and $95 \%$ air. After 6 -h ICSI, live oocytes showing two distinct pronuclei and a second polar body were considered fertilized. The fertilized eggs were further cultured in Whitten's medium supplemented with $100 \mu \mathrm{M}$ EDTA for $96 \mathrm{~h}$ at $37.5{ }^{\circ} \mathrm{C}$ in $5 \%$ $\mathrm{CO}_{2} 95 \%$ air. About $96 \mathrm{~h}$ after ICSI, the blastocysts were transferred into the uteri of pseudopregnant ICR recipients (CLEA Japan) 2.5 days postcoitum (dpc) using the embryo transfer method described by Suzuki et al. (1994). The recipient females were killed on 18.5 $\mathrm{dpc}$ to determine the number of implantation sites by macroscopic check and the number of term fetuses.

\section{Statistical analysis}

Data presented in this study were analyzed statistically by the $\chi^{2}$-test and Tukey's test for non-parametric multiple comparisons (SAS version 6.12, SAS Institute, Cary, NC, USA). In all statistical tests, the difference was considered significant when $P<0.05$.

\section{Results}

The developmental rates to the blastocyst stage of embryos from ICSI by freeze-dried spermatozoa without storage, with storage at $30^{\circ} \mathrm{C}$ for 3 days, and at $4{ }^{\circ} \mathrm{C}$ for 6 months are shown in Tables $1-3$. All the three storage conditions showed the highest rate of embryonic development when primary drying was performed at 0.37 mbar. In addition, the number of live-term fetuses produced was higher at 0.37 mbar than at other pressures for groups non-stored and stored at $4{ }^{\circ} \mathrm{C}$ for 6 months although the difference was not significant (Table 4). All fetuses were morphological normal some of the mice have since been mated and delivered normal offspring. A numerical indicator for overall efficiency of mouse production after ICSI using freezedried mouse spermatozoa was determined by dividing the ratio of the number of embryos that developed blastocysts to the number of fertilized oocytes, by the ratio of the number of live-term fetuses to the number of blastocysts transferred (Fig. 1). With storage at $4{ }^{\circ} \mathrm{C}$ for 6 months, the overall efficiency from a pressure of 0.37 mbar (10.3) or 1.03 mbar (8.8) was significantly higher than $0.04 \mathrm{mbar}$ (1.1). Moreover, with a pressure of 0.37 mbar (25.7) non-stored, the overall efficiency after ICSI was significantly higher than for $0.04 \mathrm{mbar}(17.5)$ or 1.03 mbar (6.62). The results showed that blastocyst formation was significantly higher when primary drying was performed at 0.37 mbar than at 0.04 and 1.03 mbar irrespective of the storage conditions (non-stored, $30^{\circ} \mathrm{C}$ for 3 days, or $4{ }^{\circ} \mathrm{C}$ for 6 months; Tables $1-3$, Fig. 1 ).

Percentages of spermatozoa with comet tails freezedried at $4{ }^{\circ} \mathrm{C}$ for 6 months were 100 and $96 \%$, and stored at $30{ }^{\circ} \mathrm{C}$ for 3 days were 4 and $100 \%$ respectively. Although there was no significant difference between the percentages of spermatozoa with damaged DNA at 0.04 mbar stored at $30^{\circ} \mathrm{C}$ for 3 days and of those without

Table 2 Effect of vacuum pressure at primary drying on the in vitro development of embryos generated by ICSI of freeze-dried spermatozoa stored at $30{ }^{\circ} \mathrm{C}$ for 3 days.

\begin{tabular}{|c|c|c|c|c|c|}
\hline $\begin{array}{l}\text { Vacuum pressure } \\
\text { (mbar) }\end{array}$ & $\begin{array}{l}\text { No. of oocytes } \\
\text { injected }\end{array}$ & $\begin{array}{l}\text { No. }(\%) \text { of oocytes } \\
\text { survived }\end{array}$ & $\begin{array}{l}\text { No. }(\%) \text { of oocytes } \\
\text { fertilized }^{\mathrm{a}}\end{array}$ & $\begin{array}{c}\text { No. }(\%) \text { of embryos } \\
\text { developed to two-cell }\end{array}$ & $\begin{array}{l}\text { No. }(\%) \text { of embryos } \\
\text { developed to blastocyst }\end{array}$ \\
\hline $0.04^{\mathrm{C}}$ & 251 & $175(70)^{\mathrm{a}}$ & $170(97)^{\mathrm{a}}$ & $162(95)^{\mathrm{a}}$ & $34(20)^{a}$ \\
\hline 0.37 & 161 & $117(73)^{\mathrm{a}}$ & $113(97)^{\mathrm{ab}}$ & $111(98)^{\mathrm{a}}$ & $61(54)^{b}$ \\
\hline 1.03 & 187 & $145(78)^{a}$ & $132(91)^{\mathrm{b}}$ & $129(98)^{a}$ & $25(19)^{a}$ \\
\hline
\end{tabular}

Different superscript letters within a column indicate significantly different values $(P<0.05)$.

a Percentage of oocytes survived. ${ }^{b}$ Percentage of oocytes fertilized. 'Data from Kawase et al. (2005). 
Table $3 \mathrm{Effect}$ of vacuum pressure at primary drying on the in vitro development of embryos generated by ICSI of freeze-dried spermatozoa stored at $4{ }^{\circ} \mathrm{C}$ for 6 months.

\begin{tabular}{lccccc}
\hline $\begin{array}{l}\text { Vacuum pressure } \\
\text { (mbar) }\end{array}$ & $\begin{array}{c}\text { No. of oocytes } \\
\text { injected }\end{array}$ & $\begin{array}{c}\text { No. } \% \text { of oocytes } \\
\text { survived }\end{array}$ & $\begin{array}{c}\text { No. (\%) of oocytes } \\
\text { fertilized }^{\mathrm{a}}\end{array}$ & $\begin{array}{c}\text { No. (\%) of embryos } \\
\text { developed to two-cell }^{\mathrm{b}}\end{array}$ & $\begin{array}{c}\text { No. }(\%) \text { of embryos } \\
\text { developed to blastocyst }^{\mathrm{b}}\end{array}$ \\
\hline $0.04^{\mathrm{c}}$ & 522 & $404(77)^{\mathrm{a}}$ & $367(91)^{\mathrm{a}}$ & $346(94)^{\mathrm{a}}$ & $48(13)^{\mathrm{a}}$ \\
0.37 & 213 & $156(73)^{\mathrm{a}}$ & $145(93)^{\mathrm{ab}}$ & $142(98)^{\mathrm{a}}$ & $73(50)^{\mathrm{b}}$ \\
1.03 & 267 & $187(70)^{\mathrm{a}}$ & $182(97)^{\mathrm{b}}$ & $179(98)^{\mathrm{a}}$ & $66(36)^{\mathrm{a}}$ \\
\hline
\end{tabular}

Different superscript letters within a column indicate significantly different values $(P<0.05)$.

${ }^{a}$ Percentage of oocytes survived. ${ }^{b}$ Percentage of oocytes fertilized. ${ }^{c}$ Data from Kawase et al. 2005.

Table 4 Effect of vacuum pressure at drying on the in vivo development of embryos generated by ICSI using freeze-dried spermatozoa.

\begin{tabular}{lccccc}
\hline $\begin{array}{l}\text { Vacuum pressure } \\
\text { (mbar) }\end{array}$ & $\begin{array}{c}\text { Storage temperature } \\
\left({ }^{\circ} \mathrm{C}\right)\end{array}$ & $\begin{array}{c}\text { Sperm storage time } \\
\text { (months) }\end{array}$ & $\begin{array}{c}\text { No. of blastocysts } \\
\text { transferred }\end{array}$ & $\begin{array}{c}\text { No. }(\%) \text { of implantation } \\
\text { sites }\end{array}$ & $\begin{array}{c}\text { No. }(\%) \text { of live-term } \\
\text { fetuses }\end{array}$ \\
\hline 0.04 & $\mathrm{RT}$ & non-stored & 194 & $137(71)^{\mathrm{a}}$ & $53(70)^{\mathrm{a}}$ \\
0.37 & $\mathrm{RT}$ & non-stored & 132 & $70(71)^{\mathrm{a}}$ & $4(30)^{\mathrm{a}}$ \\
1.03 & $\mathrm{nT}$ & non-stored & 99 & $28(58)^{\mathrm{a}}$ & $20(20)^{\mathrm{a}}$ \\
0.04 & 4 & 6 & 48 & $39(53)^{\mathrm{a}}$ & $4(8)^{\mathrm{a}}$ \\
0.37 & 4 & 6 & 73 & $56(85)^{\mathrm{b}}$ & $15(21)^{\mathrm{a}}$ \\
1.03 & 4 & 6 & 66 & & $16(24)^{\mathrm{a}}$ \\
\hline
\end{tabular}

Values within a column with the same superscript are not significantly different $(P>0.05)$.

storage, developmental rates to the blastocyst stage after ICSI was significantly reduced with storage. In contrast, spermatozoa freeze-dried at $0.37 \mathrm{mbar}$ and then assessed immediately (non-stored) or after storage at $4{ }^{\circ} \mathrm{C}$ for 6 months did not have comet tails (Fig. 2, Table 5). At the primary drying pressure of 0.04 mbar, the average comet tail length of spermatozoa stored at $30{ }^{\circ} \mathrm{C}$ for 3 days and at $4{ }^{\circ} \mathrm{C}$ stored for 6 months was $0.7 \pm 3.4$ and $20.2 \pm 5.0 \mu \mathrm{m}(P<0.05)$, and at $1.03 \mathrm{mbar}$, average tail length was $23.4 \pm 6.2$ and $23.0 \pm 8.4 \mu \mathrm{m}(P>0.05)$ respectively (Table 5 ).

\section{Discussion}

Preservation of freeze-dried spermatozoa for extended periods of time, potential 100 years or more, by current methods would require storage temperatures lower than $-80{ }^{\circ} \mathrm{C}$ (Kawase et al. 2005). Successful long-term preservation of mouse spermatozoa at higher temperatures requires investigation and modification of the current freeze-drying method. Although the primary drying phase is one of the most important processes in the freeze-drying process of spermatozoa, there have been no studies on the primary drying pressure. Nail et al. (2002) reported that the pressure in the freeze-dryer has to be lower than the vapor pressure of ice at the temperature of the product, and pressures of $0.04,0.37$, and $1.03 \mathrm{mbar}$ are appropriate for materials stored at $-50,-30$, and $-20^{\circ} \mathrm{C}$ respectively. Thus, in this study, we selected primary drying pressures of 0.37 and 1.03 mbar, in addition to the commonly used 0.04 mbar. Primary drying is characterized by the specimen undergoing rapid shrinkage as the ice sublimates (ice forming water vapor and leaving the specimen). In this study, $\sim 98 \%$ of the total volume of water (0.51 g wet weight) was lost. During this step, evaporative cooling keeps the temperatures low. When most ice has sublimed, heat is no longer lost by evaporative cooling and the temperature of the product usually increases sharply toward shelf temperature. Since the driving force for freeze-drying is the vapor pressure of the ice, from the standpoint of process efficiency, it is important to keep the product temperature as high as possible during primary drying (Nail et al. 2002). As we reported recently, freeze-dried sperm kept at a pressure of $0.04 \mathrm{mbar}$ and then stored at $30{ }^{\circ} \mathrm{C}$ for 3 days or at $4{ }^{\circ} \mathrm{C}$ for 3 months had the same rate of blastocyst formation (Kawase et al. 2005). Although a pressure of 0.37 mbar gave the best results when

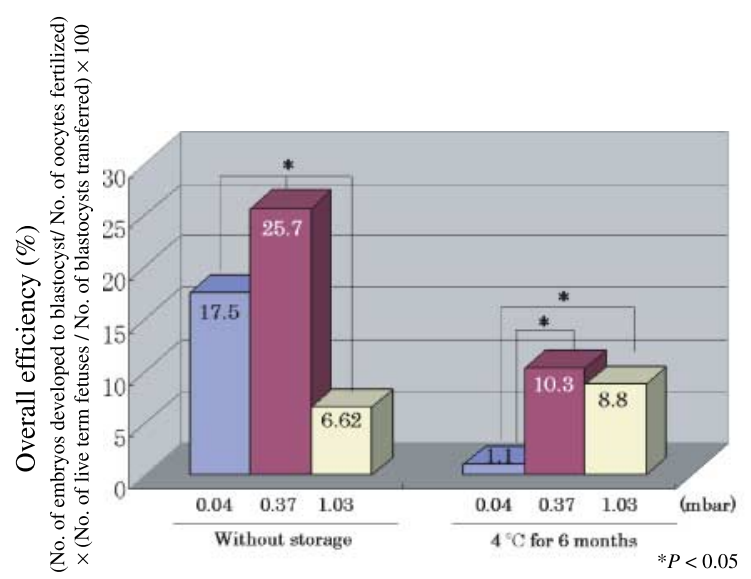

Figure 1 Overall efficiency of mouse production from ICSI using freezedried spermatozoa. Sperm were dried at 0.04 mbar (blue bar), 0.37 mbar (purple bar), or $1.03 \mathrm{mbar}$ (yellow bar) and then used for ICSI non-stored (left) or after storage at $4{ }^{\circ} \mathrm{C}$ for 6 months (right). 

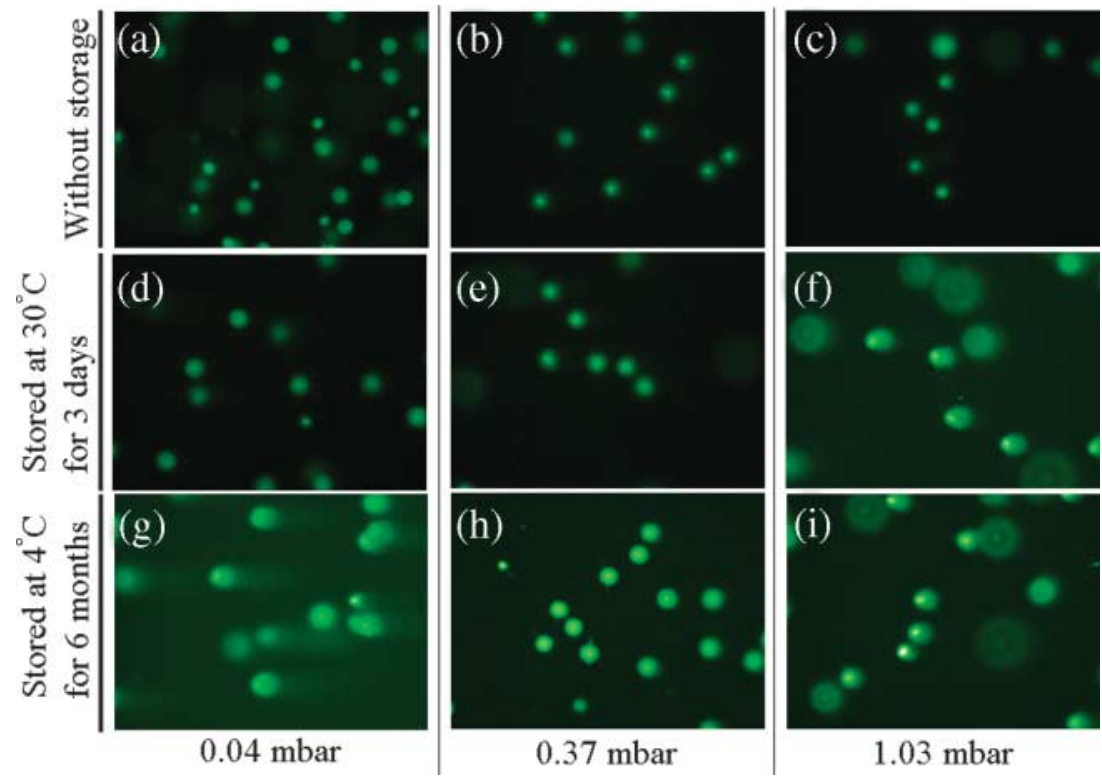

Figure 2 Comet assay of freeze-dried spermatozoa. Microscopy of spermatozoa freeze-dried at 0.04 mbar (left column), 0.37 mbar (middle column), or $1.03 \mathrm{mbar}$ (right column), with assessment immediately (top row), after storage at $30{ }^{\circ} \mathrm{C}$ for 3 days (middle row) or after storage at $4{ }^{\circ} \mathrm{C}$ for 6 months (bottom row). The presence of comet tails (halo effect) in (f), (g), and (i) indicates the presence of fragmented DNA. Original magnification $\times 200$. compared with 0.04 and 1.03 mbar, a decrease in developmental rates to blastocysts and live born was seen after storage, compared with freshly freeze-dried samples (Tables 1-4). When comparing sperm dried using three pressures, it seems that sperm dried at 0.04 mbar deteriorate significantly during storage both at 30 and $4{ }^{\circ} \mathrm{C}(P<0.05)$; sperm dried at 0.37 mbar lowers its potentials similarly during storage at 30 and $4{ }^{\circ} \mathrm{C}$ $(P<0.05)$; and sperm dried at 1.03 mbar deteriorate slightly at $30^{\circ} \mathrm{C}(P<0.05)$, but maintains its reproductive potentials when stored at $4{ }^{\circ} \mathrm{C}(P>0.05)$. Although precise mechanisms affecting storage potential in pressure at primary drying of freeze-drying mouse spermatozoa was not clarified in this study, differences of an alteration of tertiary structure in seminal proteins by freeze-drying might influence their potential (Jeyendran et al. 1983). Sperm freeze-dried at 1.03 mbar yielded the same proportion of development to blastocysts and live born after transfer when injected immediately after preservation (no storage) and after 6 months storage (Tables 1, 3, and 4). However, overall efficiency at
1.03 mbar was not significantly different between the experimental groups.

Comet assay, the evaluation of the shape of the DNA 'comet' tail and migration pattern, is widely used to measure DNA damage in many different cell types, including sperm from laboratory animals and humans (Haines et al. 1998). In this study, we performed a comet assay using alkaline electrophoresis to measure singlestranded DNA breaks and alkali-labile sites to assess the DNA integrity of individual freeze-dried sperm. Assessment of DNA damage is determined by the percentage of spermatozoa with tails and the average comet tail length. Comet tails of substantial average length were detected by comet assay at 0.04 and 1.03 mbar stored at $4{ }^{\circ} \mathrm{C}$ for 6 months and at 1.03 mbar stored at $30^{\circ} \mathrm{C}$ for 3 days (Table 5), suggesting that storage induces DNA damage in freeze-dried spermatozoa.

The overall efficiency determined from the data in this study clearly indicates that the pressure at primary drying is an important factor affecting the outcome after storage. Modifications to the freeze-drying method, with

Table 5 DNA damage (comet assay) of spermatozoa after freeze-drying and subsequent preservation.

\begin{tabular}{|c|c|c|c|c|c|c|c|c|}
\hline \multirow[b]{2}{*}{ Primary pressure } & \multicolumn{2}{|c|}{0.04 mbar } & \multicolumn{2}{|c|}{0.37 mbar } & \multicolumn{2}{|c|}{1.03 mbar } & \multicolumn{2}{|c|}{ Fresh } \\
\hline & $\begin{array}{c}\text { No. of sperm } \\
\text { with tail/total } \\
(\%)\end{array}$ & $\begin{array}{l}\text { Average of } \\
\text { tail length } \\
(\mu \mathrm{m})\end{array}$ & $\begin{array}{l}\text { No. of sperm } \\
\text { with tail/total } \\
(\%)\end{array}$ & $\begin{array}{l}\text { Average of } \\
\text { tail length } \\
(\mu \mathrm{m})\end{array}$ & $\begin{array}{c}\text { No. of sperm } \\
\text { with tail/total } \\
(\%)\end{array}$ & $\begin{array}{l}\text { Average of } \\
\text { tail length } \\
(\mu \mathrm{m})\end{array}$ & $\begin{array}{c}\text { No. of sperm } \\
\text { with tail/total } \\
(\%)\end{array}$ & $\begin{array}{c}\text { Average of } \\
\text { tail length } \\
(\mu \mathrm{m})\end{array}$ \\
\hline Without storage & $0 / 56(0)^{\mathrm{a}}$ & 0 & $0 / 62(0)^{\mathrm{a}}$ & 0 & $0 / 55(0)^{\mathrm{a}}$ & 0 & $0 / 76(0)^{\mathrm{a}}$ & 0 \\
\hline $\begin{array}{l}\text { Stored at } 30^{\circ} \mathrm{C} \\
\text { for } 3 \text { days }\end{array}$ & $2 / 55(4)^{\mathrm{a}}$ & $0.7 \pm 3.4^{\mathrm{a}}$ & $0 / 54(0)^{\mathrm{a}}$ & 0 & $50 / 50(100)^{b}$ & $23.4 \pm 6.2^{\mathrm{a}}$ & - & - \\
\hline $\begin{array}{l}\text { Stored at } 4{ }^{\circ} \mathrm{C} \text { for } \\
\quad 6 \text { months }\end{array}$ & $55 / 55(100)^{b}$ & $20.2 \pm 5.0^{\mathrm{b}}$ & $0 / 55(0)^{\mathrm{a}}$ & 0 & $49 / 51(96)^{b}$ & $23.0 \pm 8.4^{\mathrm{a}}$ & - & - \\
\hline $\begin{array}{l}\text { Stored at } 37^{\circ} \mathrm{C} \\
\quad \text { for over } 1 \text { week }\end{array}$ & - & - & - & - & - & - & $63 / 64(98)^{b}$ & $32.7 \pm 6.8$ \\
\hline
\end{tabular}

Different superscript letters between same primary pressure indicate significantly different values $(P<0.05)$. 
attention to the pressure at primary drying, will contribute to the success of permanent preservation of mammalian spermatozoa stored at higher temperatures.

\section{Acknowledgements}

We thank S Uchida and $Y$ Nakajima for their technical assistance, and Ms F Ford for proofreading the manuscript. This study was supported in part by the Special Coordination Funds for Promoting Science and Technology from the Ministry of Education, Culture, Sports and Science, Japan. The authors declare that there is no conflict of interest that would prejudice the impartiality of this scientific work.

\section{References}

Abramczuk J, Solter D \& Koprowski H 1977 The beneficial effect of EDTA on development of mouse one-cell embryos in chemically defined medium. Developmental Biology 61 378-383.

Cho C, Jung-Ha H, Willis WD, Goulding EH, Stein P, Xu Z, Schultz RM, Hecht NB \& Eddy EM 2003 Protamine deficiency leads to sperm DNA damage and embryo death in mice. Biology of Reproduction $69211-217$.

Haines G, Marples B, Daniel P \& Morris I 1998 DNA damage in human and mouse spermatozoa after in vitro-irradiation assessed by the comet assay. Advances in Experimental Medicine and Biology 444 79-93.

Hughes CM, Lewis SEM, McKelvey-Martin VJ \& Thompson W 1997 Reproducibility of human sperm DNA measurements using the alkaline single cell gel electrophoresis assay. Mutation Research 374 261-268.

Jeyendran RS, Hunter AG \& Graham EF 1983 Alteration of seminal proteins during freeze-drying of bovine semen. Journal of Daily Science 66 887-891.

Kaneko T, Whittingham DG \& Yanagimachi R 2003a Effect of $\mathrm{pH}$ value of freeze-drying solution on the chromosome integrity and developmental ability of mouse spermatozoa. Biology of Reproduction 68 136-139.
Kaneko T, Whittingham DG, Overstreet JW \& Yanagimachi R $2003 b$ Tolerance of the mouse sperm nuclei to freeze-drying depends on their disulfide status. Biology of Reproduction 69 1859-1862.

Kawase Y, Iwata T, Toyoda Y, Wakayama T, Yanagimachi R \& Suzuki H 2001 Comparison of intracytoplasmic sperm injection of inbred and hybrid mice. Molecular Reproduction and Development 60 74-78.

Kawase Y, Araya H, Kamada N, Jishage K \& Suzuki H 2005 Possibility of long-term preservation of freeze-dried mouse spermatozoa. Biology of Reproduction 72 568-573.

Kimura Y \& Yanagimachi R 1995 Intracytoplasmic sperm injection in the mouse. Biology of Reproduction 52 709-720.

Kusakabe H, Szczygiel MA, Whittingham DG \& Yanagimachi R 2001 Maintenance of genetic integrity in frozen and freeze-dried mouse spermatozoa. PNAS 98 13501-13506.

Nail SL, Jiang S, Chongprasert S \& Knopp SA 2002 Fundamentals of freeze-drying. In Development and Manufacture of Protein Pharmaceuticals, vol 14, pp 281-360. Eds SL Nail \& KJ Akers. Kluwer Academic/Plenum Publishers.

Steel EK, McClure N, Maxwell RJ \& Lewis SEM 1999 A comparison of DNA damege in testicular and proximal epididymal spermatozoa in obstructive azoospermia. Molecular Human Reproduction $\mathbf{5}$ 831-835.

Suzuki H, Togashi M, Moriguchi Y \& Adachi J 1994 Relationship between age-related decline in fertility and in vitro fertilization rate in IVCS mice. Journal of Reproduction and Development $\mathbf{4 0}$ 107-116.

Wakayama T \& Yanagimachi R 1998 Development of normal mice from oocytes injected with freeze-dried spermatozoa. Nature Biotechnology 16 639-641.

Ward MA, Kaneko T, Kusakabe H, Biggers JD, Whittingham DG \& Yanagimachi R 2003 Long-term preservation of mouse spermatozoa after freeze-drying and freezing without cryoprotection. Biology of Reproduction 69 2100-2108.

Whitten WK 1971 Nutrient requirements for the culture of preimplantation embryos in vitro. Advances in Bioscience 6 129-141.

Received 28 August 2006

First decision 18 September 2006

Revised manuscript received 29 December 2006

Accepted 9 January 2007 